\title{
3. DÉCOLLEMENT STRUCTURES ALONG THE CÔTE D'IVOIRE-GHANA TRANSFORM MARGIN
}

\author{
Jean Benkhelil, ${ }^{2}$ Michel Guiraud, ${ }^{3}$ and Joël Paccolat ${ }^{2}$
}

\begin{abstract}
Regional tectonics and detailed examination of cores recovered during Leg 159 of the Ocean Drilling Program show that four types of deformation occurred during early extension, marginal uplift and shearing of the Côte d'Ivoire-Ghana Marginal Ridge (CIGMR): (1) extensional deformation related to the opening up of pull-apart basins; (2) synsedimentary deformation related to slope instability and mass sliding of water-laden sediments; (3) deformation as a result of normal and reverse synlithification microfaulting combined with microfolding associated with well-defined, isolated, parallel-to-bedding décollement zones induced by gravity tectonics; (4) vertical shears, cleavage, and associated microfolding generated by transpressive tectonics. This paper concentrates on décollement structures (type 3 deformation). These deformations were produced by a simple shear mechanism along bedding planes that was induced by the progressive uplift of the CIGMR in the Albian during the breakup of the margin.
\end{abstract}

\section{INTRODUCTION}

The Côte d'Ivoire-Ghana Marginal Ridge (CIGMR) is a prominent bathymetric feature on the West African oceanic/continental boundary. It was formed as the Atlantic Ocean Basin opened up during Early Cretaceous times separating Africa and South America. Transcurrent motion along this transform margin has been suggested as the mechanism of separation (Mascle, 1976; Mascle et al., 1988). Geophysical data (Basile et al., 1989, 1993) indicate a broad zone of highly deformed Cretaceous sediments. Evidence of deformation was found along the southern slope of the margin during deep dives made as part of the Equanaute Survey (Mascle et al., 1993; Benkhelil et al., 1996; Guiraud et al., 1997). The primary objective of Leg 159 of the Ocean Drilling Program (ODP) was to bore into the tectonized zone of the CIGMR to investigate these deformations (Mascle, Lohmann, Clift, et al., 1996). Two to four boreholes were sunk at each of four selected sites (Fig. 1).

Microstructures were observed in the sediments at all four sites and were related to four main types of deformation: (1) synsedimentary extensional deformation; (2) syndiagenetic deformation (i.e., incompletely lithified sediments were deformed by slope instability and mass sliding of water-rich deposits); (3) shearing of isolated strata in clearly defined, parallel-to-bedding décollement zones; and (4) shearing and vertical cleavage associated with transpressive deformation (Benkhelil et al., Chap. 2, this volume).

While type 1, 2, and 4 deformations are well documented elsewhere, type 3 is uncommon. In this paper we seek to illustrate and elucidate the origins of type 3 deformation processes by using data collected during ODP Leg 159.

\section{STRUCTURAL ENVIRONMENT}

Two sets of deposits are separated by a distinct unconformity that is tentatively dated as late Albian to early Cenomanian. The sediments below the unconformity are Early Cretaceous and display a

${ }^{1}$ Mascle, J., Lohmann, G.P., and Moullade, M. (Eds.), 1998. Proc. ODP, Sci. Results, 159: College Station, TX (Ocean Drilling Program).

${ }^{2}$ URA-CNRS n 715 , Sédimentologie et Géochimie Marines, Université de Perpignan, 66860 Perpignan, France. jb@univ-perp.fr

${ }^{3}$ UMR n ${ }^{\circ} 5561$ Paléontologie Analytique et Géologie Sédimentaire, Centre des Sciences de la Terre, Université de Bourgogne, 6 Bd Gabriel, 21000 Dijon, France. wide array of structures produced by several tectonic episodes. The sediments above the unconformity are only weakly deformed if at all.

Synsedimentary deformation is apparent at all four sites, mainly below the unconformity, and consists of convolute bedding, slumped coarse-grained sandstones, water-escape structures, dewatering cleavage, and synsedimentary normal faults.

Sets of conjugate normal faults found at Site 962 are associated with variations in thickness of the sedimentary sequence and show evidence of extensional movements during lithification and before the strata were tilted (Fig. 2). The early extensional deformation observed in the Aptian to upper Albian sediments at each borehole site did not affect the uppermost Albian strata, which were subjected to a transpressional regime.

Normal faulting may also have occurred in a different setting, associated with décollement-induced deformations such as reverse faulting and folding, clearly affecting what were incompletely lithified sediments.

Vertical shear fractures observed at Site 961 exhibit associated deformation such as microfolding and closely spaced fractures resembling crenulation cleavage. While no direct evidence of wrench faulting is observed, low-pitch slickensides do occur along smallscale faults indicating some horizontal movement. These are type 4 deformations as categorized above (Benkhelil et al., Chap. 2, this volume). Mineralization by calcite, siderite, pyrite, quartz, dolomite, kaolinite, and, at depth mostly barite, is common whether as fissure filling or associated with breccia.

\section{DÉCOLLEMENT-RELATED DEFORMATIONS}

The close association between fracturing and microfolding was observed in cores from Holes 960A, 961D, and 962D. Fractures may display either reverse or normal offset, features which are usually confined to a few strata (Figs. 3-6). The fracture network may be complex, the rock being split into fragments that have moved relative to each other and rotated along either normal or reverse listric fault planes (Fig. 4; Pl. 1).

The fault planes are not discrete features but are formed by an anastomosing network of irregular iron-coated fractures. The sediment is extensively fragmented and the pieces have been displaced and rotated along planes of sliding (Fig. 4). Locally the rock is completely disorganized and the sliding planes seem to be arranged entirely at random. In other samples there is a consistent geometrical pattern between the normal and reverse faults and the orientation of 


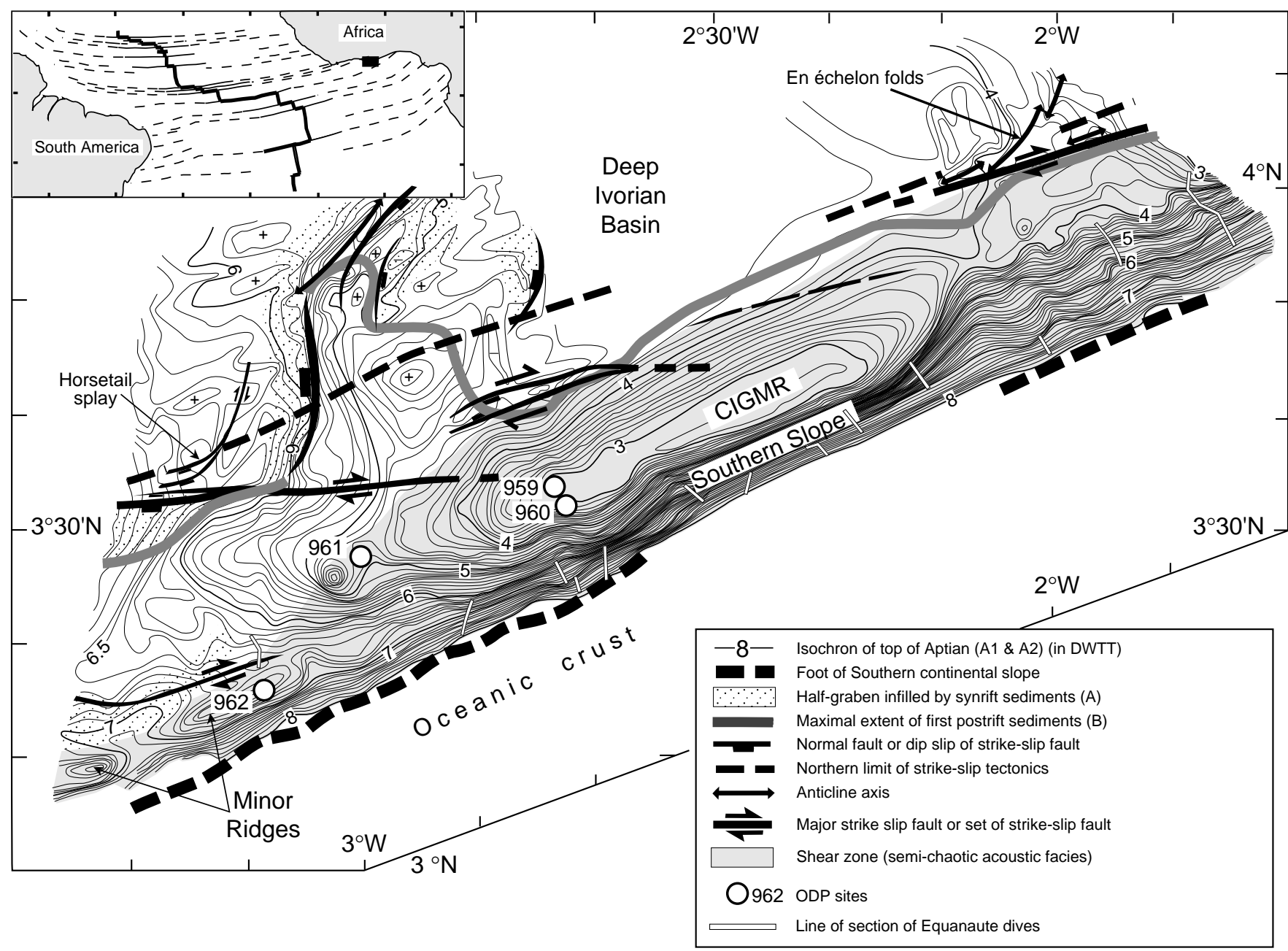

Figure 1. Structure of the Côte d'Ivoire-Ghana Marginal Ridge (CIGMR) and location of the Leg 159 sites (modified from Basile et al., 1993). Contours are two-way traveltime to the top of the deformed sediments.

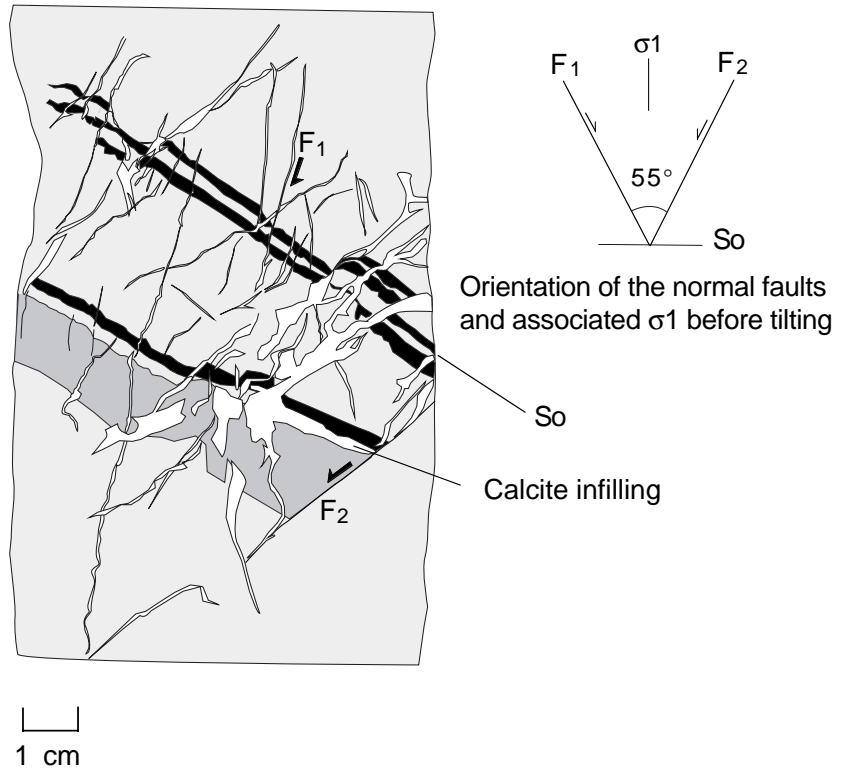

Figure 2. Conjugate normal faults formed before tilting of the sedimentary series. Notice the lateral thickness variations developed during the extensional regime and the calcite veins infilling fractures (Sample 159-962D-6R$\mathrm{CC}, 2-11 \mathrm{~cm})$. the axial planes of folds. Normal and reverse microfaults are commonly found together in isolated laminae of alternating siltstones and claystones (Fig. 3B). Two specific types of normal microfault are observed. The first family F1 (Fig. 3B) is characterized by dipping in the opposite direction to the reverse microfaults, which are clearly associated with asymmetric drag microfolds. A second family of normal microfaults F2 and F3 (Fig. 3B) dips in the same direction as the reverse faults. The fault planes of these microfaults are wavy as a result of subsequent deformation (F2 in Figs. 3B, 5B). The microfaults are rooted in parallel-to-bedding décollement zones. The normal faults dip at $55^{\circ}-70^{\circ}$ to the bedding. Their traces are generally wavy and small parallel faults are found in their vicinity. Some terminate at bedding planes with certain samples exhibiting bed-to-bed slip features such as high-pitch slickensides. A number of rollover structures are observed (Fig. 4). The deformation of the normal microfault planes is interpreted as the result of a two-stage process illustrated by Figure 3. In a first stage, the strata are submitted to an extensional regime resulting in a set of conjugate normal faults. In a second stage, a parallel-to-bedding shearing accompanied by décollement zones is responsible for reverse faulting and associated asymmetric microfolding. According to their orientation, former normal faults were reactivated or indented by the shearing (Figs. 3B, 5B).

\section{Folding}

The folds are generally limited to part of the strata in extent. In the less deformed levels, most simple folds with slightly dipping axial 

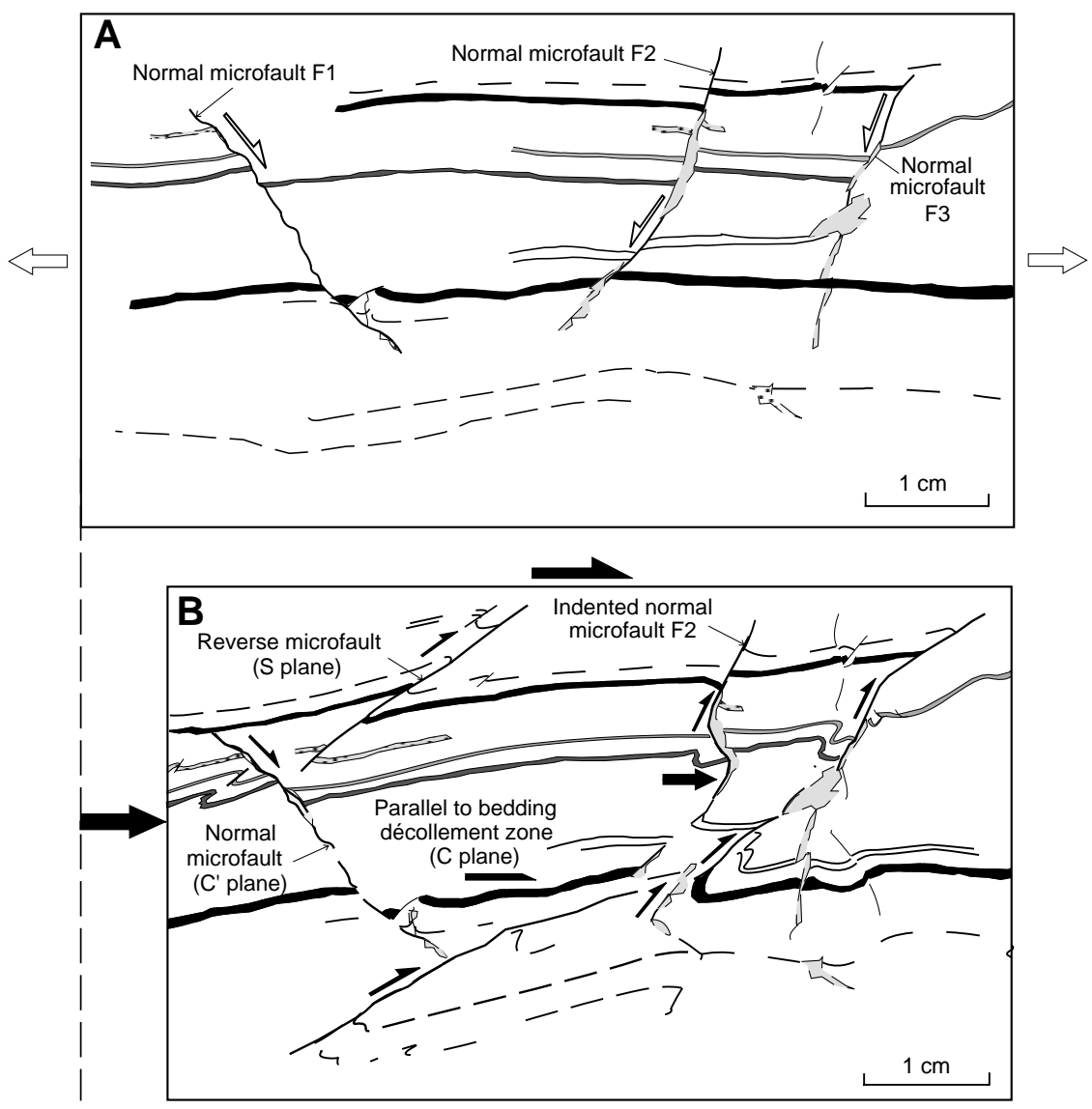

Figure 3. Décollement microstructures associating normal and reverse microfaults as well as asymmetric microfolds (Sample 159-960A-54R-3, 30-31 cm). A. Early conjugate normal microfaults (F1 to F3) formed prior to tilting of bedding. B. Décollement deformation producing asymmetric microfolds, reverse microfaults (S planes) and normal microfaults ( $\mathrm{C}^{\prime}$ plane). The décollement motion is responsible for the indentation of early normal microfaults F2 and F3.

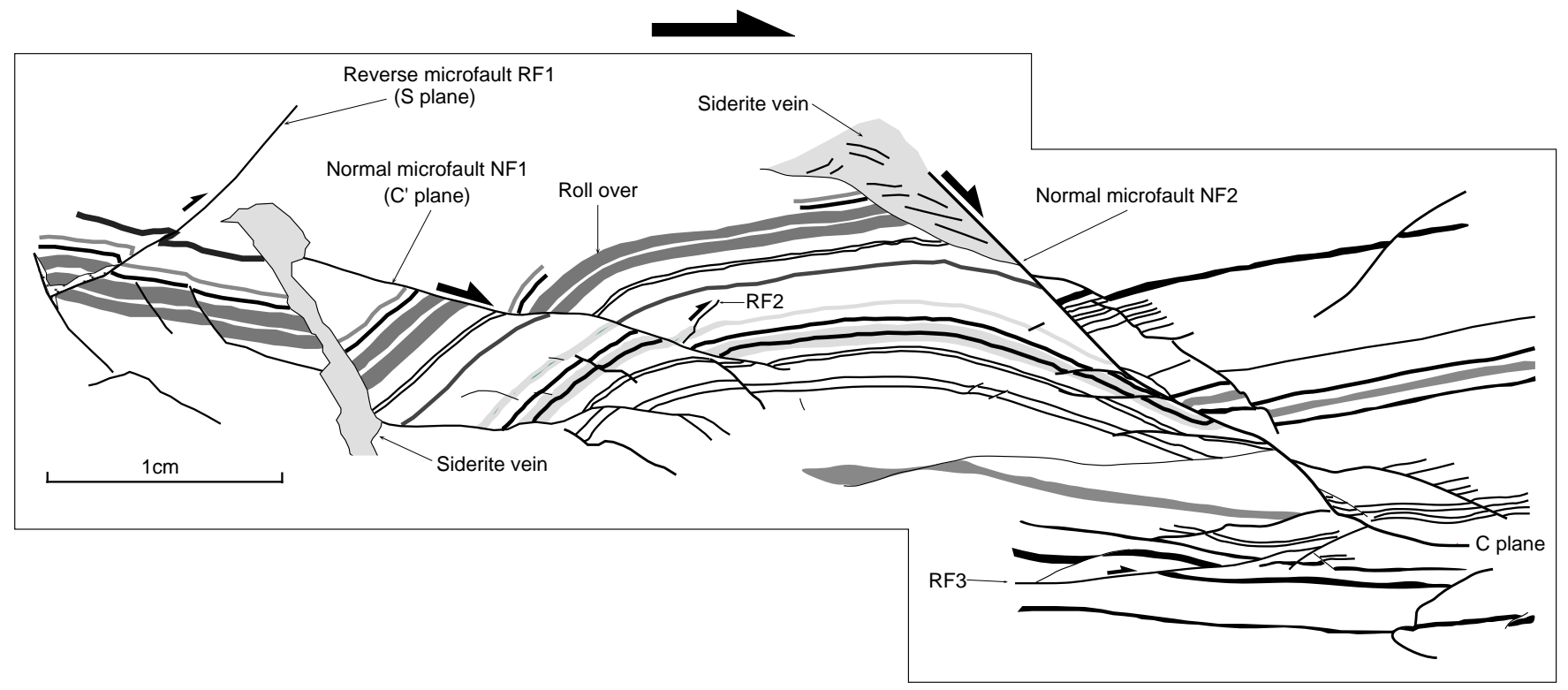

Figure 4. Interpretative sketch of décollement-induced microstructures (Sample 159-960A-54R-3, 33-35 cm). Normal microfaults (NF1 and NF2) correspond to the $\mathrm{C}^{\prime}$ planes and become parallel to bedding (décollement surface $\mathrm{C}$ ). The reverse fault RF1 is associated with an asymmetric microfold with axial plane ( $\mathrm{S}$ plane) dipping in the same direction. 
Figure 5. Interpretative sketch of décollement-induced microstructures showing an association of normal faults, reverse faults, and asymmetric microfolds (Sample 159-962D-12R-5, 87-89 cm). A. Early conjugate normal microfaults $(\mathrm{F} 1, \mathrm{~F} 2)$ formed due to horizontal extension (open arrows). B. Décollement $\mathrm{F} 1$ is reversely reactivated while $\mathrm{F} 2$ is indented due to translation along bedding. Large black arrow shows the direction of motion related to décollement. Small black arrow indicates the sense of the movement, which deforms the early normal faults. deformation stage where the early normal microfault

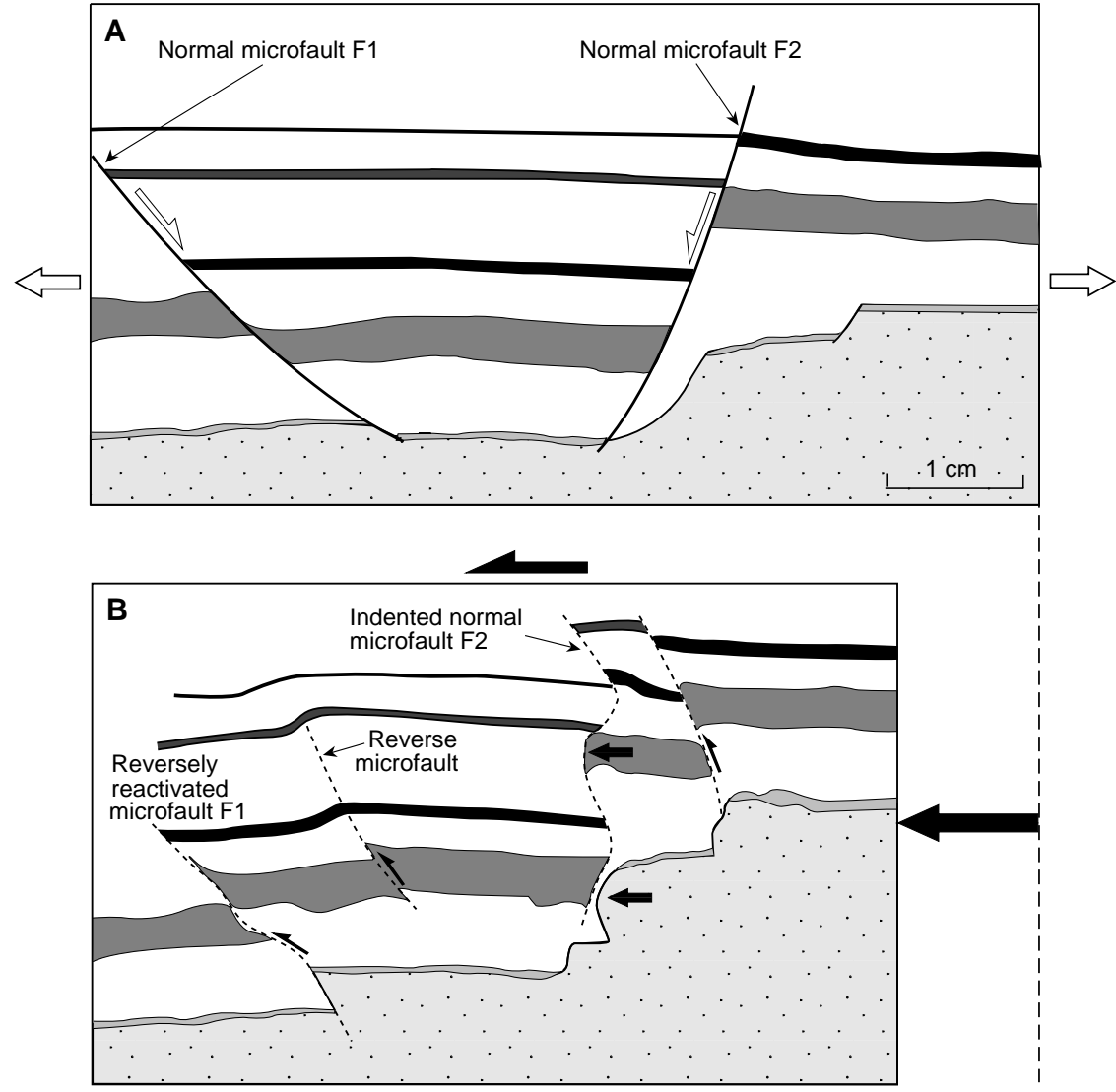

both in superficial shears (Marcoux et al., 1987) and deep shears (Cobbold and Quinquis, 1980). Such geometries are typical of simple shear deformation.

Microscope observation of the thin section in Figure 6 reveals two units of differing lithology and structure separated by erosive discontinuities, D1 and D2. The upper unit is undeformed fine-grained sandstone. The lower unit is composed of alternating thin sandstone and claystone beds deformed by a set of asymmetric folds and reverse microfaults related to parallel-to-bedding shears. This arrangement clearly shows the early origin of the shear deformation.

\section{Rheological Conditions of Deformation}

Figure 6. Shear slump with asymmetric microfolds and associated reverse faults (Sample 159-960A-59R-2, 60-62 cm). D1 and D2 are erosional discontinuities. The short limbs of asymmetric drag microfolds are sheared and pass into small reverse faults. Arrow indicates the direction of motion related to décollement.

planes vary from rounded to double hinged, resulting at a more advanced stage in pop-up structures (Figs. 3B, 5B; Pls. 2, 3). Asymmetric folds with normal limbs display extensional strain (normal faulting, boudinage) whereas short limbs exhibit compressional strain (reverse faulting). The extension that occurred along the low-dipping limb indicates the contrasts in competence between layers during deformation. Upright near-symmetrical buckle folds (Pl. 2) result from weak simple shear deformation through bedding-parallel shortening. The core is commonly disharmonic (Pls. 2, 3).

The more deformed zones exhibit isoclinal microfolds with disharmony in the inner part of the folds and parallel to bedding axial planes similar to the fold structures observed along other superficial shears (Farrell and Eaton, 1987; Hibbard and Karig, 1987; Marcoux et al., 1987; Pls. 4, 5). When viewed in cross section, some of the folds exhibit an eye-like structure characteristic of sheath folds found
The deformed material consists mainly of siltstones and claystones, although fine-grained sandstones are sometimes affected too. The deformations are clearly visible in isolated thin layers. Waterrich sediment was deformed at an early stage. Folding with no related cleavage and detached fold hinges (Pl. 4), liquefied sediment flow structures, and sand dikes are evidence of the high moisture content of the sediments. Upright and inclined folds developed without significant internal disorganization except locally in the core of the folds where disharmony occurred (Pl. 3). The irregular traces of the faults related to ramp-flat geometry are caused by refraction of the more competent beds indicating a degree of lithification (Figs. 3B, 5B). The dragging effects of the strata across the fault plane attest to the ductility of the material and demonstrate the synlithificational nature of the deformation.

\section{DEFORMATION MECHANISM}

Microstructural analysis highlights the spatial co-existence of extensional microfaults and asymmetric microfolds associated with 
subparallel-to-bedding microshears located throughout certain clay strata that acted as décollements. The angular relationships between the limits of the décollement zone and the normal and reverse microfaults within the zone are similar to those found between the $\mathrm{C}^{\prime}$ and $\mathrm{S}$ planes and the limits of a typical $\mathrm{C}$ ductile shear band. These angular relationships can be used to determine the kinetics of the $\mathrm{C}$ shearing (Berthé et al., 1979; Fig. 7). The décollements parallel to bedding are clearly indicative of compressed sectors characterized by asymmetric folding and reverse faulting, which are commonly associated (plane S), and extensional zones where boudinage and normal faults develop (plane $C^{\prime}$ ) dipping in the opposite direction to the reverse faults (Fig. 7).

At most Leg 159 sites, complex relationships are observed between décollement, and extensional and compressional microfaults, reflecting two stages of deformation A and B (Figs. 3, 5). At stage 1 (Figs. 2, 3A, 5A), the system of conjugate normal microfaults affected untilted strata, reflecting parallel-to-bedding extension related with the regional transtension of the CIGMR syntransform stage (Benkhelil et al., Chap. 2, this volume).

At stage 2, deformation associated with décollements was superimposed on earlier structures (Figs. 3B, 5B). The normal microfaults assimilated to $\mathrm{C}^{\prime}$ planes dip in the opposite direction to the reverse microfaults (plane $S$ ) associated with asymmetric drag microfolds. The axial planes of the asymmetric folds are parallel to the reverse faults, and in some instances, the short limb of the fold developed into a reverse fault. Disharmony often developed in the inner part of the folds (Pl. 3). Some of the first-generation normal microfaults are reactivated as reverse faults while others display wavy traces, are not reactivated, and are therefore deformed only by indentation as a result of translational movements (Figs. 3B, 5B).

The initial sediment geometry (thinly laminated sandstones) and rheology (stage of lithification) are also significant factors in determining the style of deformation. In this type of sedimentary environment, the motive force of the décollement structures is related to sloping effects. This driving force acting on unlithified sediments produces gravity-induced displacement related to tangential shear parallel to bedding. Schack Pedersen (1987) argues for distinguishing gravity gliding and gravity spreading. In the first case, the deformation is caused by a mass moving downslope under its own weight. In the second case, deformation is caused by loading from an overlying body. In the case in point, criteria indicate that features such as axial plane cleavage or load-affected microfolds are evidence of gravity spreading. This mechanism supposes that the deformed rocks are not superficial but are overlain by a series of strata making up the overlying body. The parallel-to-bedding shear induced by sliding of the overlying body can be likened to a heterogeneous simple shear giving

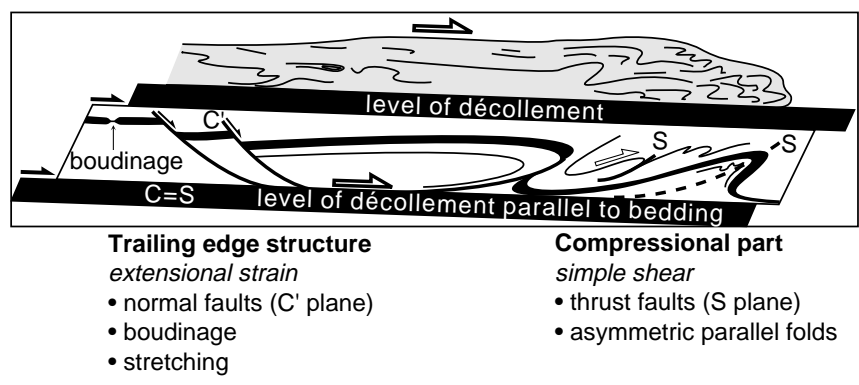

Figure 7. Sketch showing the deformation related to décollement zones induced by a slump mass causing shearing by loading observed in the Leg 159 samples. The décollement surface ( $\mathrm{C}$ plane) is parallel to the bedding and may pass to reverse faults or terminate in the axial plane of asymmetric fold ( $S$ planes). The normal faults ( $C^{\prime}$ planes) and boudinage result from the extensional strain, which affects the trailing edge of the structure. rise to a system of reverse and compressional features (reverse microfaults to thrusts and inclined microfolds, Fig. 7).

At low gradients of deformation, the load produced buckling and boudinage, then sliding of the overlying mass deformed the folds to form inclined folds. The development of these structures depended on the amount of displacement of the overlying body, the most mature stage being a complex imbrication of thrust sheets.

\section{CONCLUSIONS}

Microstructural analysis of samples from Leg 159 of the ODP reveals four types of deformation. The first is characterized by establishment throughout the Aptian to upper Albian sediments of normal conjugate microfault systems and is related to the syn-rift episode of the Ivory Coast-Ghana Transform Margin. The second and third types were synsedimentary to synlithification deformation both associated with normal and reverse microfaulting and asymmetric microfolding, which are related to localized parallel-to-bedding décollements (Fig. 8A). The fourth type, related to the syntransform transpressive stage, is described elsewhere (Benkhelil et al., Chap. 2, this volume).

The results of microstructural analysis are integrated within the scale of the transform margin. There is a clear increase in the intensity of deformation from base to top of the ridge (Fig. 8A, B). This arrangement compounded by the flower structures detected by seismic profiling (Basile et al., 1993; Fig. 8A) can be used to relate the structuring of the Ivory Coast-Ghana Ridge to an overall extensional and subsequently strike-slip tectonic framework. We suspect that uplift associated with the strike-slip motion (Fig. 8B) probably induced substantial gravitational instability giving rise to the many parallelto-bedding décollements observed in the ODP samples (Fig. 8A).

The model under development in this paper unites in a single coherent system the emplacement of the décollements and the uplift of the axial part of the Ivory Coast-Ghana Ridge produced by a single mechanism combining strike-slip flower structuring and local gravity induced tectonics.

\section{ACKNOWLEDGMENTS}

This manuscript is a contribution of the CNRS URA 715.

\section{REFERENCES}

Basile, C., Mascle, J., Auroux, C., Bouillin, J.P., Mascle, G., Goncalves de Souza, K., and la Groupe Equamarge, 1989. Une marge transformante type, la marge continentale de Côte d'Ivoire-Ghana: résultats préliminaires de la campagne Equamarge II, mars 88. C. R. Acad. Sci. Ser. 2, 308:997-1004.

Basile, C., Mascle, J., Popoff, M., Bouillin, J.P., and Mascle, G., 1993. The Côte d'Ivoire-Ghana transform margin: a marginal ridge structure deduced from seismic data. Tectonophysics, 222:1-19.

Benkhelil, J., Guiraud, M., Mascle, J., Basile, C., Bouillin, J.-P., Mascle, G., and Cousin, M., 1996. Enregistrement structural du coulissage Afrique/ Brésil au sein des sédiments crétacés de la marge transformante de Côte d'Ivoire-Ghana. C. R. Acad. Sci. Ser. 2, 323:73-80.

Berthé, D., Choukrome, P., and Jegouzo, P., 1979. Orthogneiss, mylonite and non-coaxial deformation and granites: the examples of South American shear zone. J. Struct. Geol., 1:31-42.

Cobbold, P., and Quinquis, H., 1980. Development of sheath folds in shear regimes. J. Struct. Geol., 2:119-126.

Farrell, S.G., and Eaton, S., 1987. Slump strain in the Tertiary of Cyprus and the Spanish Pyrenees: definition of palaeoslopes and models of soft-sediment deformation. Geol. Soc. Spec. Publ. London, 29:181-196.

Guiraud, M., Benkhelil, J., Mascle, J., Basile, C., Mascle, G., and the Equanaute Team, 1997. Syn-rift to syn-transform deformation along the Côte d'Ivoire-Ghana transform margin: evidence from deep-sea dives. GeoMar. Lett., 17:70-78. 
Hibbard, J., and Karig, D.E., 1987. Sheath-like folds and progressive fold deformation in Tertiary sedimentary rocks of the Shimanto accretionary complex, Japan. J. Struct. Geol., 9:845-857.

Marcoux, J., Brun, J.P., Burg, J.P., and Ricou, L.E., 1987. Shear structures in anhydrite at the base of thrust sheets (Antalya, Southern Turkey). J. Struct. Geol., 9:555-561.

Mascle, J., 1976. Le golfe de Guinée: un exemple d'évolution de marge atlantique en cisaillement. Mem. Soc. Geol. Fr., 128.

Mascle, J., Blarez, E., and Marinho, M., 1988. The shallow structures of the Guinea and Ivory Coast-Ghana transform margins: their bearing on the Equatorial Atlantic Mesozoic evolution. Tectonophysics, 155:193-209.

Mascle, J., Guiraud, M., Basile, C., Benkhelil, J., Bouillin, J.P., Cousin, M., and Mascle, G., 1993. La marge transformante de Côte d'Ivoire-Ghana: premiers résultats de la campagne Equanaute (Juin 1992) [The Côte
d'Ivoire-Ghana transform margin: preliminary results from the Equanaute cruise (June 1992)]. C. R. Acad. Sci. Ser. 2, 316:1255-1261.

Mascle, J., Lohmann, G.P., Clift, P.D., et al., 1996. Proc. ODP, Init. Repts., 159: College Station, TX (Ocean Drilling Program).

Schack Pedersen, S.A., 1987. Comparative studies of gravity tectonics in Quaternary sediments rocks related to fold belts. In Jones, M.E., and Preston, R.M.F. (Eds.), Deformation of Sediments and Sedimentary Rocks. Geol. Soc. Spec. Publ. London, 29:165-180.

Date of initial receipt: 30 September 1996

Date of acceptance: 4 June 1997

Ms 159SR-008

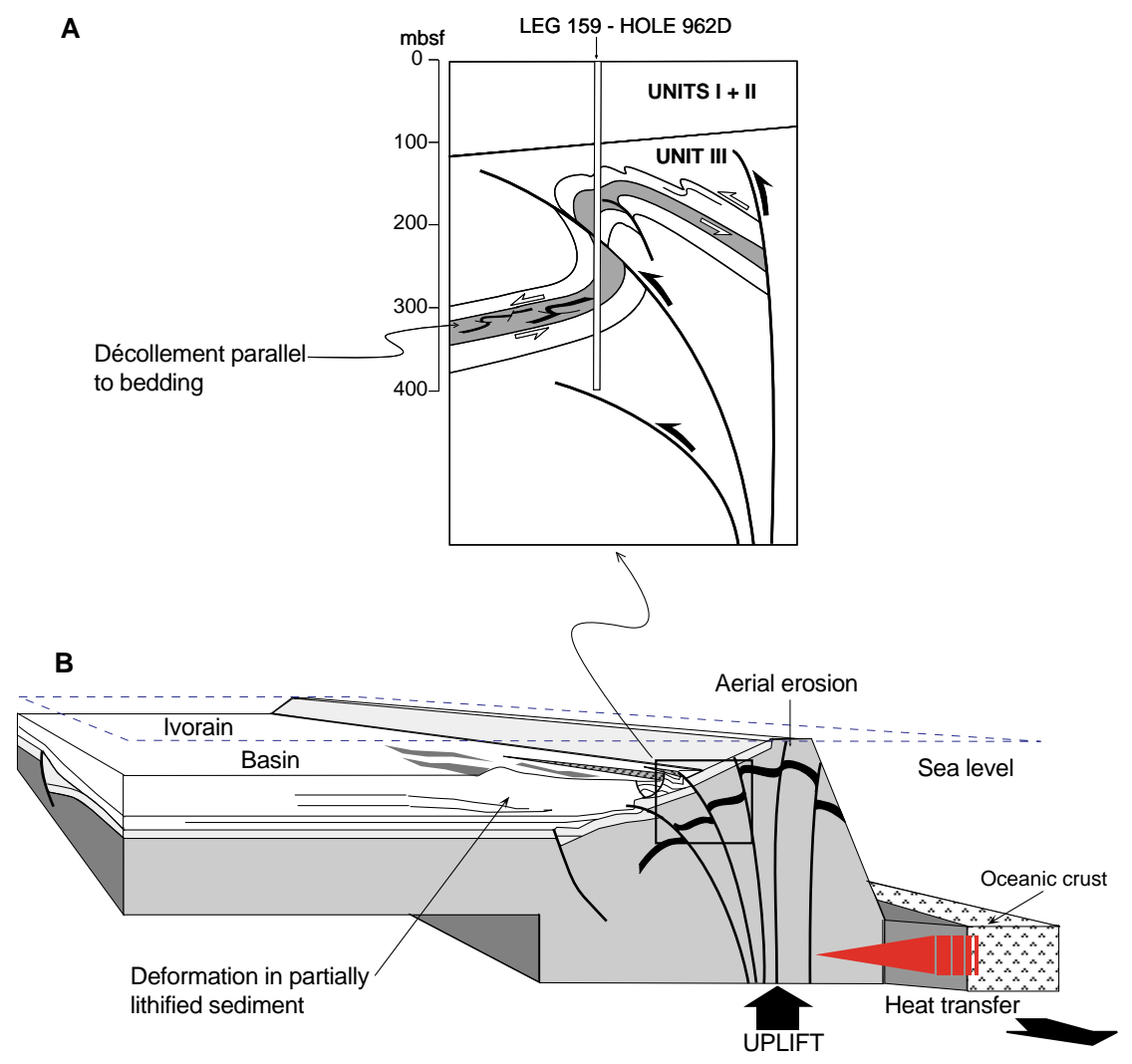

Figure 8. Tentative model of the CIGMR and adjacent Deep Ivorian Basin combining (A) strike-slip flower structure, and (B) local gravity-induced tectonics. The décollement zones are a direct consequence of the uplift of the CIGMR. 


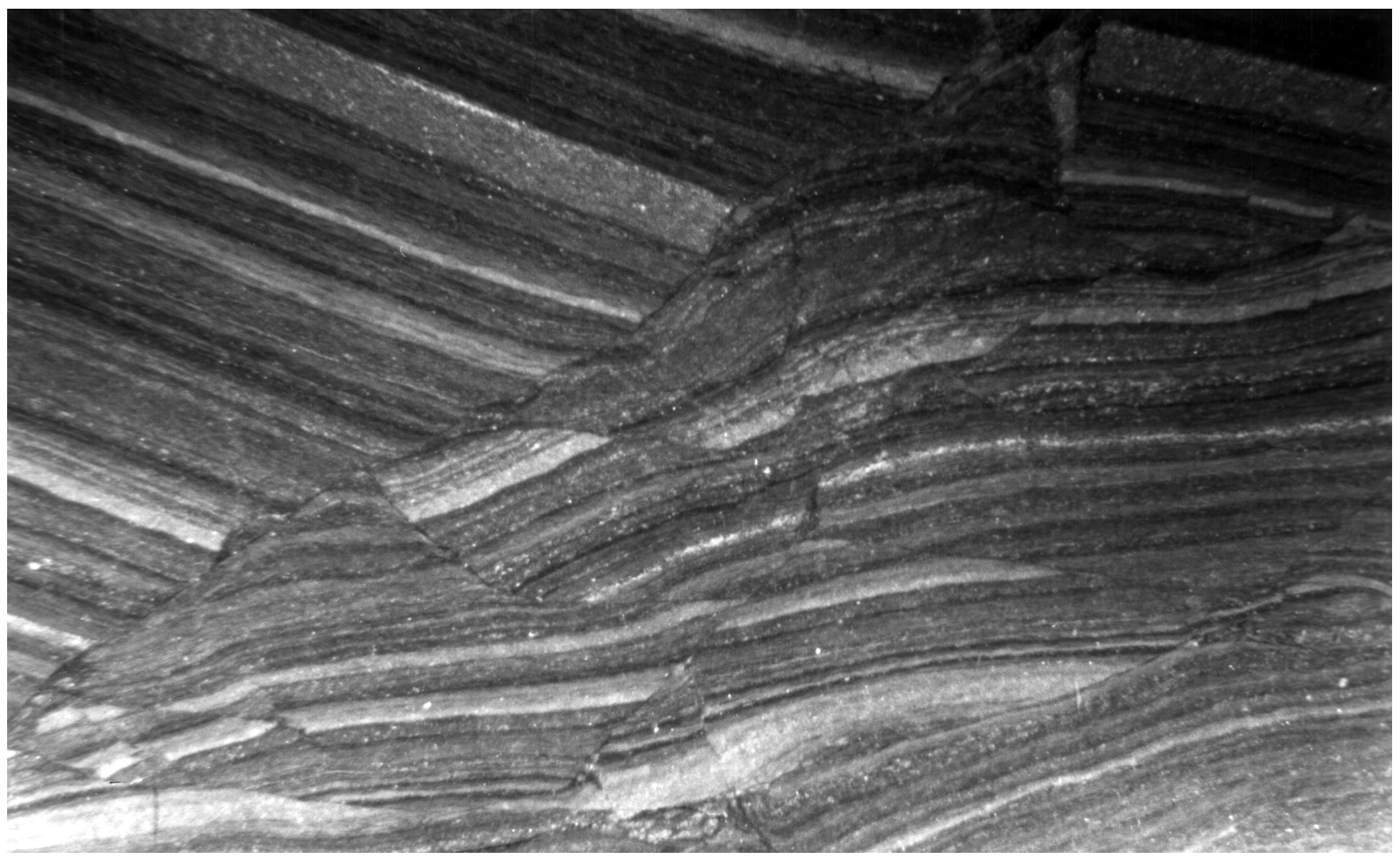

Plate 1. Set of listric faults resulting in a complex pattern of offset and rotated fragments in laminated siltstones (Sample 159-960A-54R-3, 32-34 cm).

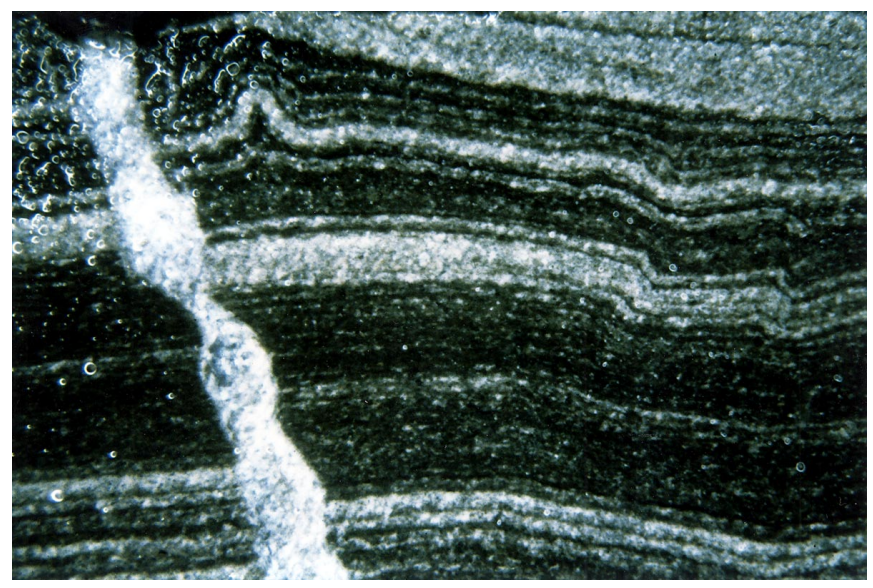

Plate 2. Buckling microfold and asymmetric kink microfolds with a normal fault filled with calcite (Sample 159-962D-28R-1, 75-77 cm). Note that axial plane of kink microfolds dips in the opposite direction to that of normal fault. 


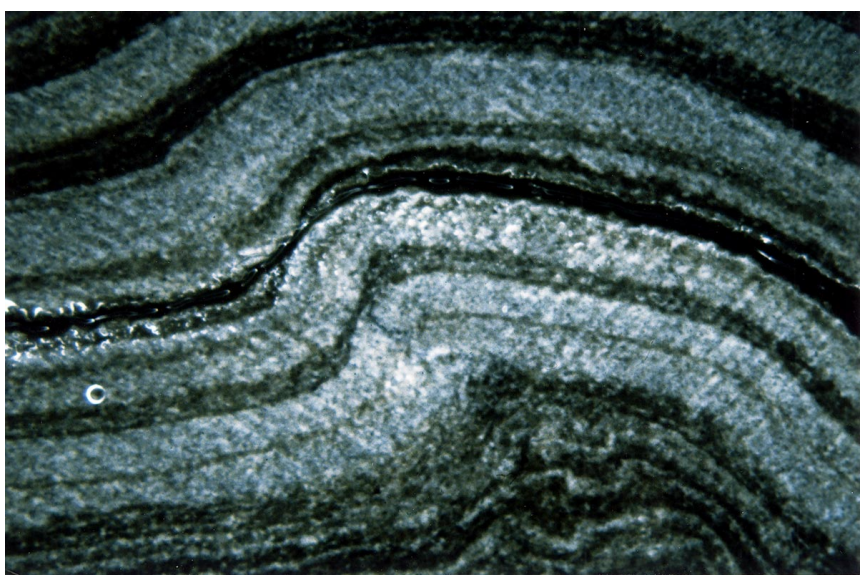

Plate 3. Asymmetric microfold showing disharmony in the core (Sample 159-962D-33R-CC, 4-5 cm).

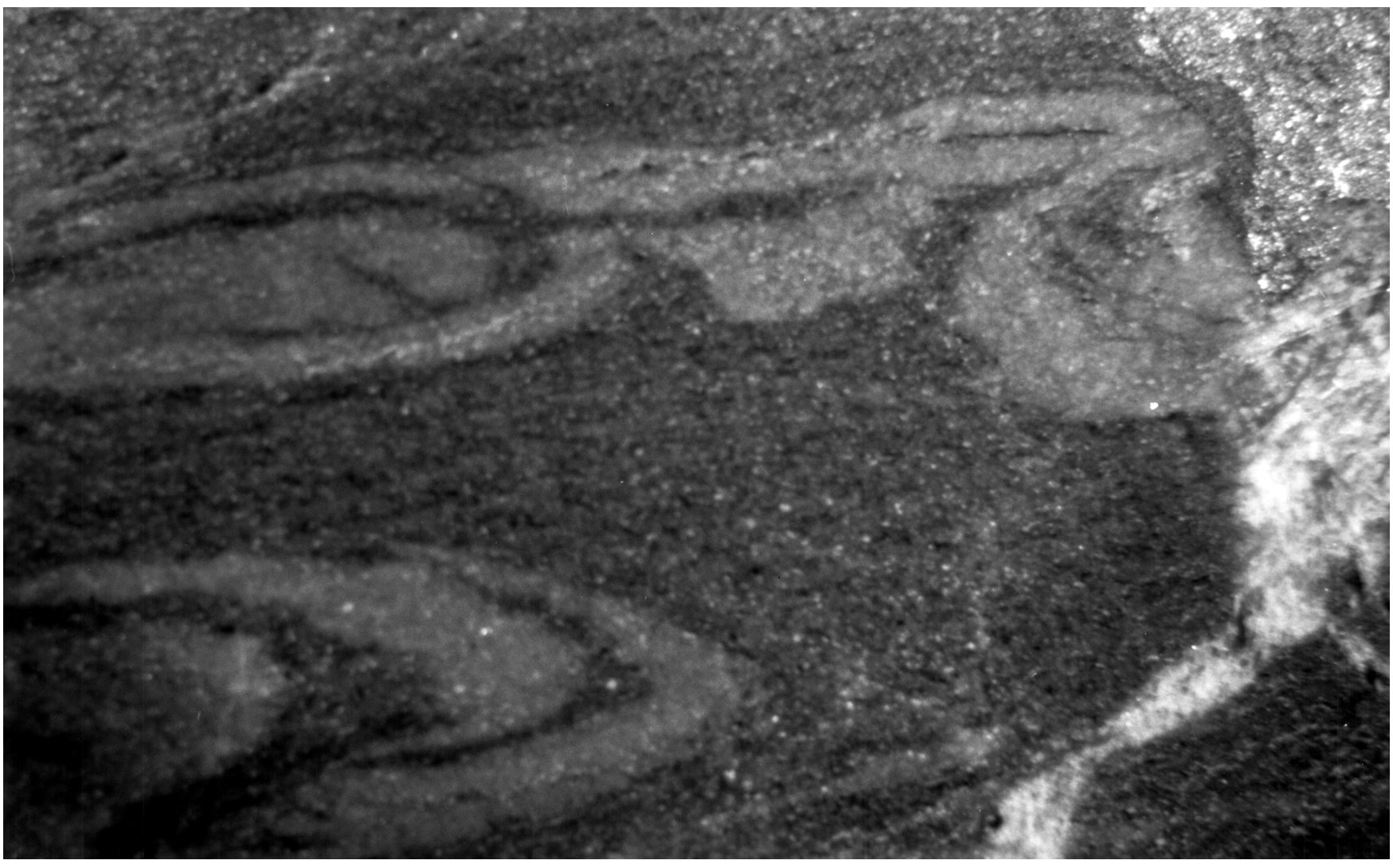

Plate 4. Refolded fold and detached fold hinges in water-rich sediment (Sample 159-960A-47R-1, 13-17 cm). 


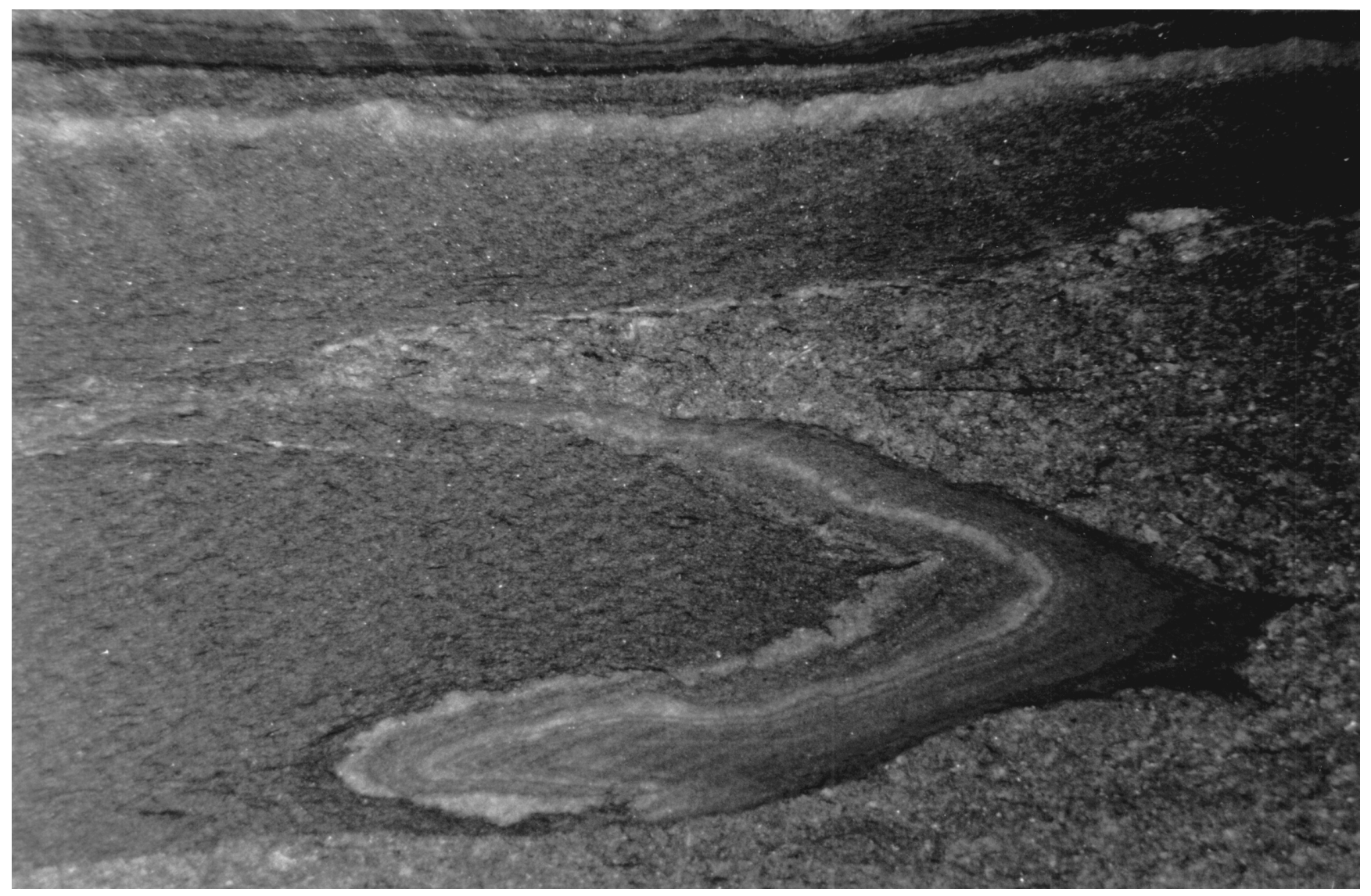

Plate 5. Isoclinal disharmonic microfolds with subhorizontal axial planes and associated incipient cleavage defined by alignment of micas (Sample 159$960 \mathrm{~A}-54 \mathrm{R}-3,32-34 \mathrm{~cm})$. 